\title{
Potential Contribution of Waste-to-Energy to Power Consumption in the Gaza Strip
}

\author{
Mazen Abualtayef ${ }^{a}$, Reem Elghossain ${ }^{a}$, Mahmoud Shatat ${ }^{b, *}$, Israa Abushaban ${ }^{a}$ \\ ${ }^{a}$ Environmental Engineering Department, the Islamic University of Gaza, Gaza, Palestine \\ ${ }^{b}$ Institute of Sustainable Energy Technology - University of Nottingham, Nottingham, NG7 2RD - UK
}

\begin{abstract}
Sustainable energy supply is one of the main challenges that people will face over the coming decades. Biomass can make a substantial contribution to supplying future energy demand in a sustainable way. Currently it is the largest global contributor of renewable energy, and has significant potential to expand the production of heat, electricity and fuels for transport. Municipal solid waste is an enormous renewable resource that has high energy capacity because it contains a high proportion of biomass materials. This kind of sustainable waste management typically called waste-to-energy is critical for reducing the reliance on fossil fuels and non-renewable materials. Waste-to-energy is a reliable and alternative form of energy that has become the basis for many of the most successful solid waste management systems in many countries. Energy recovery from waste is the conversion of waste materials into useable heat, electricity, or fuel through a variety of processes. This study assesses the potential contribution of waste-to-energy facilities to total Gaza peak power demand up to the year 2040 based on three scenarios: incineration, anaerobic digestion and landfill gas recovery. Three dumping sites are distributed along the Gaza Strip, Johr El-deek, Deir El-balah and Rafah. The analysis shows a potential to produce about $1100 \mathrm{MWh}$ per day based on the anaerobic digestion scenario, about $580 \mathrm{MWh}$ per day based on incineration of municipal solid waste scenario, and about $130 \mathrm{MWh}$ per day based on landfill gas recovery scenario. These values accounts to $275 \%, 145 \%$ and $33 \%$ of the year 2014 peak electricity demand of 400 megawatt from the three scenarios, respectively. The forecasted results of the three scenarios can be used to design future waste-toenergy facilities in the main cities of the Gaza Strip. The production cost of energy was $7 \phi / \mathrm{kWh}, 5 \phi / \mathrm{kWh}$ and $17 \varnothing / \mathrm{kWhfor}$ incineration, anaerobic digestion and landfill gas recovery scenarios, respectively.
\end{abstract}

Keywords: Municipal solid waste, Biomass, Waste-to-Energy, Cost.

\section{Introduction}

Gaza Strip's demand for energy and electricity is increasing rapidly and heavily dependent on expensive imported conventional energy resources that place a big burden on the economy. Gaza's power supply comes from three sources. Gaza receives 120-140 megawatt (MW) from Israeli's Electricity Company about 30\%, 27 MW from Egypt a small power supply of about $7 \%$, and $100 \mathrm{MW}$ generated by a local power plant in Gaza with

* Corresponding author.

E-mail: mahmoodshatat@hotmail.com

(C) 2015 International Association for Sharing Knowledge and Sustainability

DOI: $10.5383 /$ ijtee.09.02.003 electricity generating capacity of some $25 \%$. Gaza power plant produces electricity at high prices compared to the price of electricity purchased from Israel, mainly due to the high price of diesel used for the plant. Only $257 \mathrm{MW}$ is available from a total consumption of $400 \mathrm{MW}$ so far, which lead to a permanent deficit of about $143 \mathrm{MW}$ with a percentage of $36 \%$, this consumption is predicted to increase to $830 \mathrm{MW}$ by 2020 [1]. 
The Gaza Strip's population is about 1.70 million in 2013 with a population density of about 4,660 capita per square kilometer, which increases the demand on electricity [2].

The deficit between electricity demand and supply causes eight to twelve hours of scheduled power outages per day. A limited and diminishing supply of electricity to the Gaza Strip is placing ever increasing pressure on the delivery of basic services in health, education, water and sanitation to a growing Palestinian population [3].

Therefore, the above discussion presents sufficient reasons to look for new alternatives of energygeneration. In this regard, biomass energy appears to be one of the most efficient and effective solutions for clean and sustainable energy development in the Gaza Strip, which shall assist in minimizing the power shortages and develop the energy industry sector in the Gaza Strip.

Biomass can make a substantial contribution to supplying future energy demand in a sustainable way. Currently it is the largest global contributor of renewable energy resource, and has significant potential to expand in the production of heat, electricity and fuels for transport [4]. Biomass resources suitable for energy production cover a wide range of materials. Municipal solid waste is an enormous renewable resource that contains high amounts of energy because it consists of a high proportion of biomass materials such as paper/cardboard, wood and food [5].

Municipal solid waste (MSW) generation ranged from 0.4 to $0.6 \mathrm{~kg} / \mathrm{capita} /$ day in rural areas and refugee camps, and 0.9 to $1.2 \mathrm{~kg} /$ capita/day in cities [6,7].

The current practice of waste disposal in the Gaza Strip is dumping waste in open landfills. The current applied central dumping sites are Johr El Deek landfill (3 million tons of waste so far), located southeast of Gaza city, the Deir El Balah dump site (1.6 million tons of waste), located east of Deir Al Balah city and the Al Fukhari land fill (300,000 tons of waste) located east of Rafah city [8].

Waste-to-energy (WTE) is a reliable and renewable form of energy that has become the basis for many of the most successful solid waste management systems in many countries. Energy recovery from waste is the conversion of waste materials into useable heat, electricity, or fuel through a variety of processes. This kind of sustainable waste management typically called WTE, which is critical for reducing our dependence on fossil fuels and non-renewable materials and improving our environment [5]. WTE systems can reduce the amount of MSW deposited in landfill sites by up to $90 \%$ depending upon material composition and degree of recovery, which in turn can reduce the area required of landfills by $90 \%$ [9].

The exploitation of MSW as source of biomass energy will achieve long-term solid waste management solutions. Energy recovery can be achieved by various methods of managing waste including incineration of
MSW, anaerobic digestion and landfill gas (LFG) recovery.

Incineration involves the combustion of typically unprepared (raw or residual) MSW. To allow the combustion to take place a sufficient quantity of oxygen is required to fully oxidize the fuel. Incineration plant combustion temperatures are in excess of $850 \mathrm{oC}$ and the waste is mostly converted into carbon dioxide and water and any noncombustible materials (e.g. metals, glass, stones) remain as a solid, known as incinerator bottom ash (IBA) that always contains a small amount of residual carbon [10].

Combustible gas can be produced from biomass through the low temperature biological processes called anaerobic digestion. Biogas is the common name for the gas produced either in specifically designed anaerobic digesters or in landfills by capturing the naturally produced methane.

After waste placement in a landfill, a portion of organic waste (such as paper, food waste, and yard trimmings) decomposes. Landfill gas is produced by microorganisms under anaerobic conditions and is comprised of approximately $50 \% \mathrm{CH}_{4}, 50 \% \mathrm{CO}_{2}$, and trace amounts of non-methane organic compounds (NMOC). Significant LFG production typically begins one or two years after waste is buried in a landfill and can continue for 10 to 60 years or longer as long as organic waste is present [11].

\section{Materials and Methods}

\subsection{Incineration of MSW}

The composition and the produced quantities of MSW in the Gaza Strip were obtained from previous studies. The forecasted amounts of MSW from 2013 to 2040 (ton/day) were divided into two main incineration stations are as shown in Figure 1 [8].

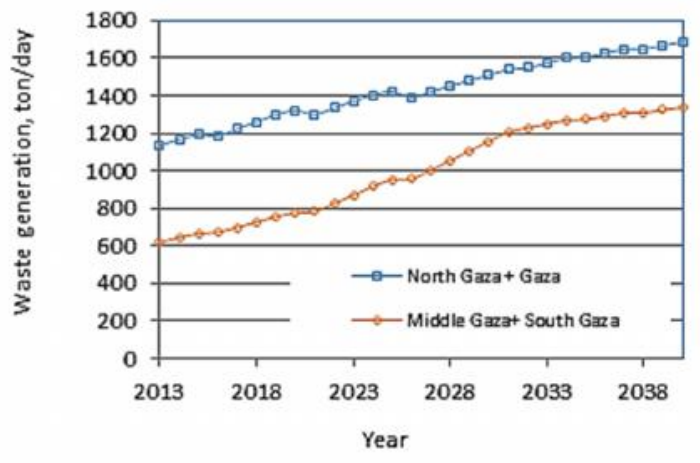

Figure 1: Forecasted waste generation for the two stations

The two stations will cover the energy demand in Gaza Strip by dividing the Strip into two main areas, where 
Johr El Deek station will serve Gaza and North Gaza, and Al fukhari station will serve the middle and South area of Gaza.

The composition of the MSW for the two proposed stations shown in Figure 2 was found to be approximately the same with small differences in some components. e.g. the percent of paper was nearly the same, while the percent of plastic was higher in North Gaza and Gaza station [8].
The total organic waste fraction is $50 \%$ in North-Gaza station and $62 \%$ in Middle-South station, while sand and fine materials make up a substantial portion of the waste volumes $14.41 \%$ and $13.33 \%$ in North-Gaza station and Middle- South station, respectively.

In this study a moisture content of $70 \%$ was used as a worst case [12].

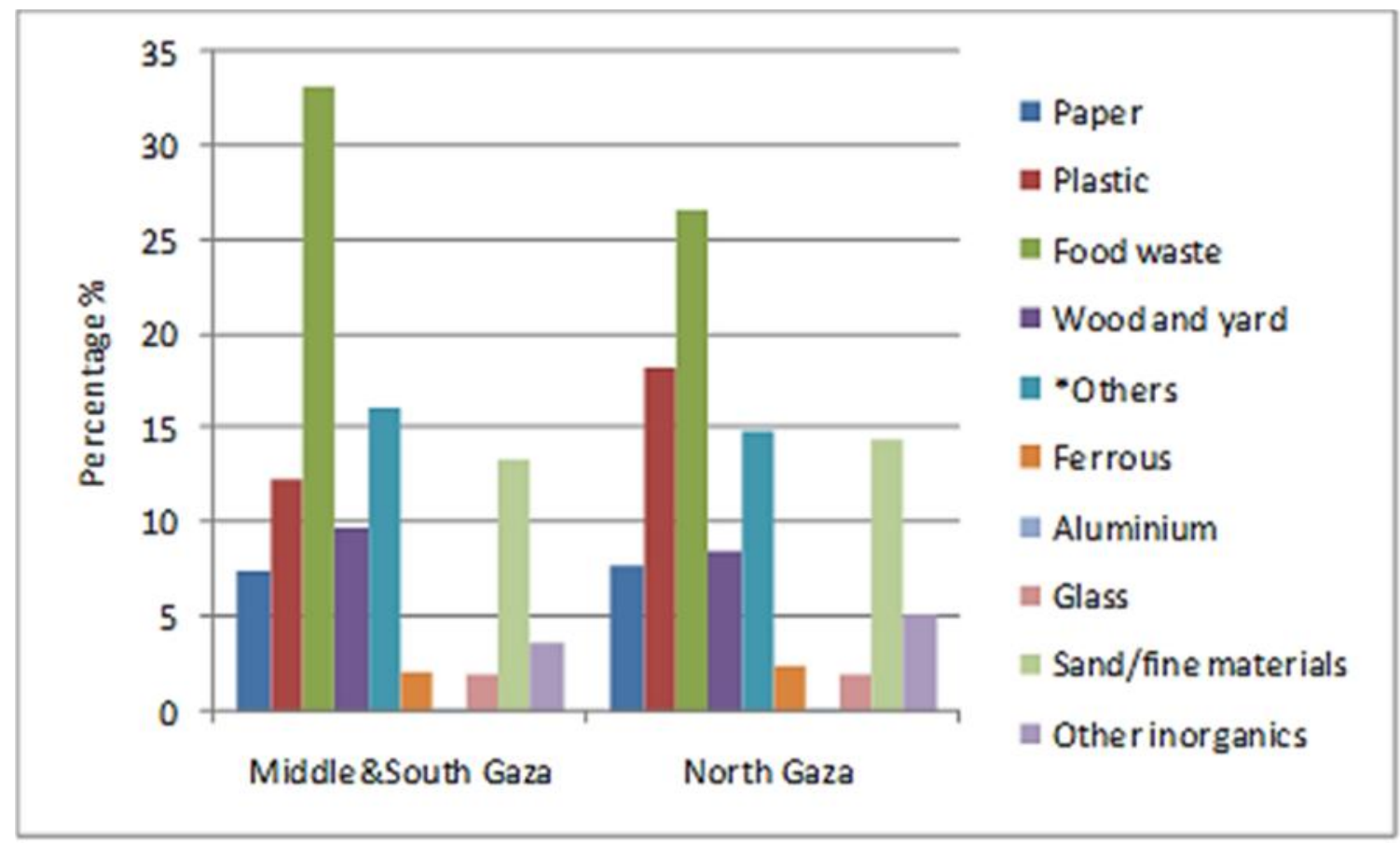

Figure 2: The composition of MSW in the two stations

*Other include textiles, diapers and other organics.

An incinerator producing exclusively heat can have a thermal generating efficiency of around $80-90 \%$; this heat may be used to raise steam for electrical generation at approximately $17-30 \%$ gross efficiency. Net electrical efficiencies (taking into account the parasitic load of the plant) are often cited up to $27 \%$ for incinerators recovering electricity only, although some facilities have reported exceeding this percentage. The choice of a steam turbine generator set to produce electricity will limit the upper efficiency based on acceptable boiler temperatures [10].

The energy content of the main combustible components was taken as the typical value [13], as shown in Figure 3.

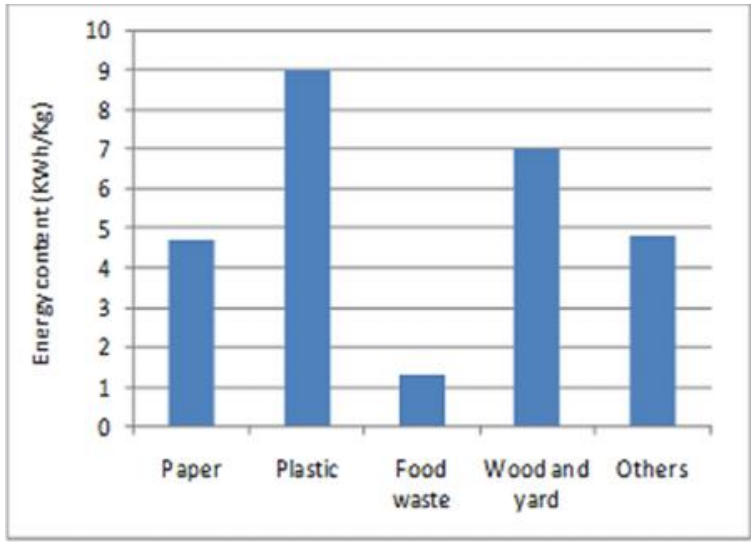

Figure 3: Energy content of combustible waste components

To obtain the total amount of energy generated from the incineration, two different scenarios were considered. In the first scenario plastic was included in the composition of combusted waste, while in the other one it was excluded. In both scenarios, the following steps were undertaken, firstly the non-combustible fraction of waste 
such as ferrous and aluminum materials, glass and sand were excluded from calculations, and then the percentage of combustible materials was $78.7 \%$ and $76.03 \%$ in Middle-South station and North-Gaza station, respectively. Secondly, the weight of each combustible component was calculated using equation (1):

$$
W_{X}=P_{X} \cdot W_{T}
$$

Where:

$W_{X}$ is the weight of the combustible component $x$ (paper, plastic, wood and yard, food waste and others) in ton/day.

$P_{X}$ is the percentage of the combustible component $x$.

$W_{T}$ is the total weight of waste in ton/day.

Thirdly, calculate the total energy generated from the combustible components in MWh/day, using equation (2):

$$
\mathrm{E}=\sum W_{X} \cdot E_{X}
$$

Where:

$E$ is the energy from the combustible fraction in $\mathrm{MWh} /$ day.

$E_{X}$ is the energy content of the combustible component $x$ in $\mathrm{kWh} / \mathrm{kg}$.

Finally, the moisture content was taken into account that goes high up to $70 \%$ and assuming a $30 \%$ efficiency of incineration, and then the actual total energy generated is:

$$
\begin{gathered}
E_{T}=\text { Efficiency } \times(1-\text { moisture } \%) \times E \\
E_{T}=0.3 \times 0.3 \times E
\end{gathered}
$$

The difference in calculations between the two scenarios is the elimination of plastic in the second one, which accounts for $12.28 \%$ and $18.29 \%$ in Middle-South station and North-Gaza station, respectively.

To find out the economic value of the incineration, a scenario of selling the produced energy based on an energy price of $140 \mathrm{US} \$ / \mathrm{MWh}$. This is the current price of energy in the Gaza Strip, which was summed to see the potential economic return.

In order to know the environmental advantages of the incineration of MSW in Gaza, the Waste Reduction Model (WARM), which was created by the U.S. Environmental Protection Agency EPA, has been used to track and report greenhouse gas (GHG) emissions reductions from several different waste management practices.

In order to attain the optimal design of incinerators and their cost in the Gaza Strip, two companies from two different countries were contacted. The companies offered different scenarios for the design of the incineration units, which in turn affect the total cost of energy. In all cases, the annual maintenance cost was assumed to be $4-6 \%$ of the investment cost, and the interest rate was taken as $6 \%$ during a useful life of 20 years.

\subsection{Landfill Gas Recovery}

LandGem model [14] was used for predicting the generated gas from three main landfills in the Gaza Strip. LandGem model is an automated tool for estimating emission rates for total landfill gas, methane, carbon dioxide. LandGemis based on a first-order decomposition rate equation for quantifying emissions from the decomposition of landfilled waste in MSW landfills and to estimate annual emissions over a time period based on user specification. The equation is as follows [14]:

$$
\mathrm{QCH} 4=\sum_{\mathrm{i}=1}^{\mathrm{n}} \sum_{\mathrm{j}=0.1}^{1} K L o\left(\frac{\mathrm{Mi}}{10}\right) \mathrm{e}^{-\mathrm{Kt} \mathrm{ij}}
$$

Where:

$\mathrm{QCH}_{4}$ is the annual methane generation in the year of the calculation in $\mathrm{m}^{3} /$ year.

$i$ is one year time increment.

$n=$ year of calculation - initial year of waste acceptance

$j$ is 0.1 year time increment.

$k$ is the methane generation rate $\left(\right.$ year $^{-1}$ )

$L_{o}$ is the potential methane generation capacity in $\mathrm{m}^{3} / \mathrm{Mg}$.

$M_{i}$ is the mass of waste accepted in the $i$ th year in $\mathrm{Mg}$.

$T_{i j}$ is the age of the jth section of waste mass $\mathrm{Mi}$ accepted in the ith year (decimal years, e.g., 3.2 years).

$1 \mathrm{Mg}$ is equal to 1 ton.

In the model, the input parameters for landfill include the landfill open year, the closure year, the rate of solid waste acceptance per year, the methane generation rate constant (k), the methane generation potential (Lo), and concentrations of selected air pollutants as shown in Table 1. 
Table 1: The model input parameters for the landfills

\begin{tabular}{|l|c|c|c|}
\hline Parameters & $\begin{array}{c}\text { Jahr El Deek } \\
\text { landfill }\end{array}$ & $\begin{array}{c}\text { Deir E1 Balah } \\
\text { landfill }\end{array}$ & $\begin{array}{c}\text { Al Fukhari } \\
\text { landfill }\end{array}$ \\
\hline Landfill open year & 1987 & 1996 & 1998 \\
\hline Landfill closure year & 2032 & 2013 & 2040 \\
\hline Methane generation rate constant, $k\left(\right.$ year $\left.^{-1}\right)$ & 0.04 & 0.04 & 0.04 \\
\hline Methane generation potential, $L_{0}\left(\mathrm{~m}^{3 / \mathrm{Mg})}\right.$ & 100 & 100 & 100 \\
\hline Methane content(\% by volume) & 50 & 50 & 50 \\
\hline
\end{tabular}

The quantity of disposed solid waste at three landfills during the life of landfills and the waste amount in place at the opening of site to the closure of site are presented in Figure 4. Since there was a lack of the data available about the quantity of disposed solid waste during the earlier years, a prediction of the missing data were made according to the population in these areas and municipal solid waste generation per capita per day.

The amount of power generated can be computed using the electrical conversion efficiency as in the following equation (5):

$$
\mathrm{EE}(\mathrm{kWh})=\mathrm{V}_{\mathrm{LFG}} \mathrm{XLHV}_{\mathrm{LFG}} \mathrm{XRX \eta}
$$

Where:

$\mathrm{EE}$ is the electric energy in $\mathrm{kW}$.

$\mathrm{V}_{\mathrm{LFG}}$ is the LFG flow rate in $\mathrm{m}^{3} / \mathrm{h}$.

$\mathrm{LHV}_{\mathrm{LFG}}$ is the lower heating value of $\mathrm{LFG}$ in $\mathrm{kWh} / \mathrm{m}^{3}$.

$\mathrm{R}$ is the recovery rate.

$\eta$ is the engine electric energy conversion efficiency.

LHV Biogas is equal to $6.1 \mathrm{kWh} / \mathrm{m}^{3}$.

LHV Methane is equal to $10 \mathrm{kWh} / \mathrm{m}^{3}$.

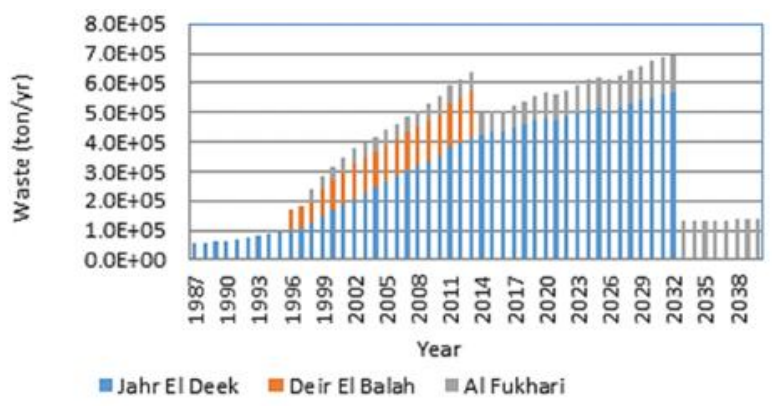

Figure 4: The quantity of MSW at three landfills

\subsection{Anaerobic Digestion}

Anaerobic digestion of the organic fraction of MSW provides an engineered and highly controlled process of capturing methane, especially when compared to landfill gas capture of methane generated by waste. Typically, digestion of mixed solid waste is conducted as part of the compliance with directives to stabilize the organic fraction of the waste stream prior to disposal. The current trend is toward anaerobic digestion of source separated organic waste streams, including food waste and paper. Presorting is necessary to prevent clogging of the pumps and to reduce the amount of reactor volume occupied by inert material. Even source-separated waste inevitably contains metal and plastic contaminants and must be presorted.

For an effective anaerobic digester system design of the three landfills, different specializing companies were contacted to obtain the optimal design system. The proposed plant was designed to convert in energy all the waste excluding recyclable materials. The plant is composed of three sub-plants (16):

\section{Pretreatment process}

Undifferentiated waste material is delivered to an enclosed, negative pressure airflow receiving area equipped with a bio-filter to prevent odors from spreading outside the facility. After bulky and dangerous materials manual removal, waste is delivered to the sorting line composed of the following steps: shredder, conveyors to inert and metals removal machine, and press extruder, where the waste is squeezed through a high-pressure machine and separated into wet fraction and dry fraction.

\section{Anaerobic digestion with biogas production}

The wet fraction is delivered from the press extrusion process to a cleaning system to remove impurities and sand to dilute it. Then the waste is sent to the software controlling an aerobic digestion phase where it is converted into biogas, stabilized soil improver and nitrogenous water. Biogas is used to run a cogeneration unit to produce electrical and thermal energy. Soil improver can be used in agriculture, in landfill cultivation or in the remediation of contaminated soils. 
Nitrogenous water is delivered to a de-nitrification and oxidizing plant before recycling it at the top of the plant and prior to discharge into the sewage network.

3. Steam boiler to process refuse derived fuel and produce energy

The dry material coming from sub-plant is refusing derived fuel. It is a stable material and will be converted into energy through the very low emission (VLE) specific grate steam boiler. A turbine is fed with the steam to produce electrical and thermal energy. Electric energy is processed locally through a power station and sold to the national electric grid (16)

The Gaza Strip was divided into three anaerobic digestion plants, Johr El-Deek plant will serve Gaza and the north, Deir El-Balah plant will serve the middle area and Rafah plant will serve the south.

\section{Results and Discussion}

\subsection{Incineration of MSW}

The estimations of the daily energy generated from the two stations in the Gaza Strip are presented in Table 2. It can be seen that the total energy generated by the year 2013 is about $374 \mathrm{MWh} /$ day and $186 \mathrm{MWh} /$ day in North-Gaza station and Middle-South station, respectively. This energy is expected to reach $556 \mathrm{MWh}$ /day and $402 \mathrm{MWh} /$ day by the year 2040 in the two stations, respectively. The results are for the scenario with plastic content of MSW. While for the other scenario, it can be noticed that the energy generated is much less; this is due to the high-energy content of plastic materials.

The WTE will also bring economic advantages through fuel savings and income from energy sale, which will allow the facility to be self financing, revenues must cover operating and maintenance costs, including depreciation and financing expenses. The potential energy production and income from energy sale depends mainlyon the energy content (net calorific value) of the waste. Figure 5 shows the potential income from sale of energy for the three stations in the Gaza Strip based on an electricity price of US\$140/MWh.

Further, WARM model was used to calculate the GHG emissions reductions in metric tons of carbon dioxide equivalent (MTCO2E) and total change in energy use in million BTU in the case of using incineration of MSW as waste management practice instead of landfilling.

For baseline scenario, the waste management practice was landfilling and the alternative scenario was combustion, which resulted in a reduction of 5,494 MTCO2E in GHG emissions. Table 3 and Table 4 show the total change in GHG emissions and energy use, respectively.

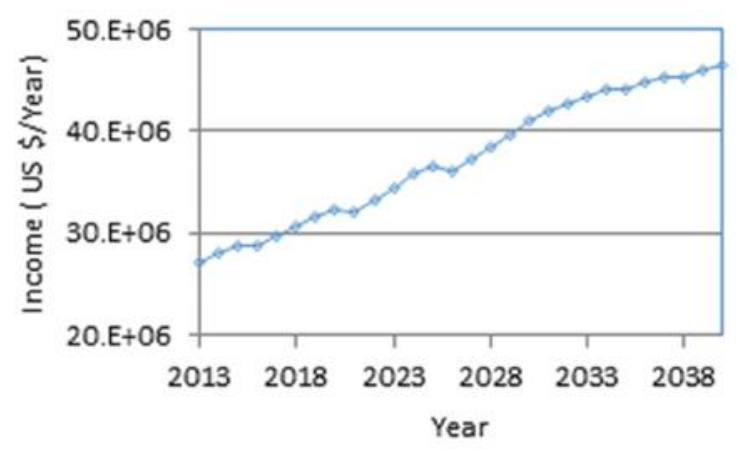

Figure 5: Yearly energy sales income for the two stations

Total emissions estimates are provided by this model may not sum due to independent rounding. This energy is equivalent to: conserving 81 households' annual energy consumption; conserving 1,570 barrels of oil and conserving 72,963 gallons of Gasoline.

The actual investment cost of waste incineration plant depends on many factors, especially the size of the plant, the number of metric tons per year or day and the corresponding lower calorific value of the waste. Lowcapacity plants are relatively more expensive than highcapacity plants in terms of investment cost per metric ton of capacity. For the Gaza Strip's stations the estimated cost was different between the two companies, depending on the design and the capacity of the incinerator, and the amount of energy that can be generated from a specific amount of waste. The results from the two companies are illustrated in Table 5.

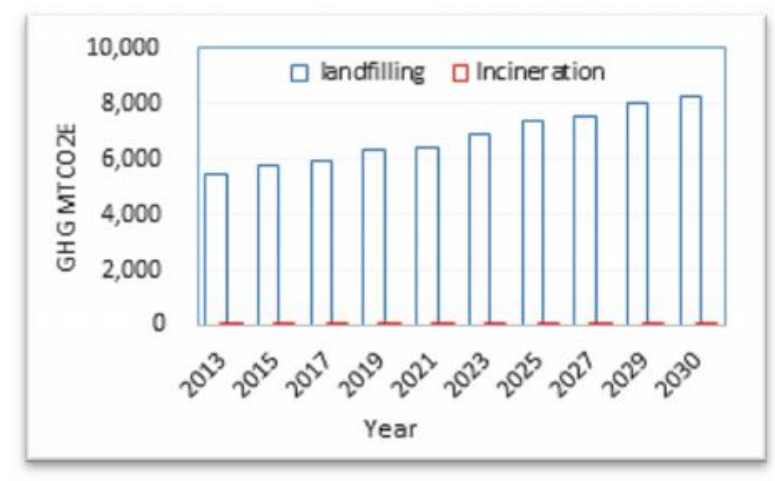

Figure 6: GHG emissions from different waste management practices in the Gaza Strip

The Santes Company produced systems up to 5 ton/hour operated 24 hours per day and the approximate capital cost for such plant is US\$20 million. For the Gaza Strip's plant multiple line of this system will be used. At this capacity such a system could generate about 3$4 \mathrm{MWh}$. The production cost of energy is US\$ $0.05 / \mathrm{kWh}$. Similarly Winderichx company suggested that the installation of 14 ton/hour is about US\$70 million. At this capacity, such a unit could generate about 3.6 MWh. The production cost of energy is US $\$ 0.19 / \mathrm{kWh}$. 


\subsection{Landfill gas recovery}

A projection of the LFG generation using LandGem model was developed for Johr El Deek, Deir El Balah and Al Fukhari landfills. Figure 7 shows the gas production profile of Johr El Deek landfill. The results demonstrated that the amount of landfill gas would keep on increasing until it reached a maximum in 2033. This would generate $34.1 \mathrm{Mm}^{3}$ methane and $68.1 \mathrm{Mm}^{3} \mathrm{LFG}$ gas. After 2032, no more waste would be placed on the present available space. However, the landfill gas would continue to produce but at a lower rate.

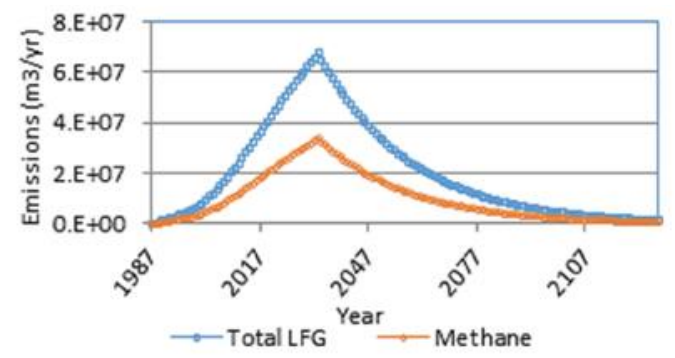

Figure 7: LFG generation from Jahr El Deek landfill

For Deir El Balah landfill, Figure 8 shows the landfill gas production profile, which reached its maximum in 2014 where $6.3 \mathrm{Mm}^{3}$ methane would be produced and 12.6 $\mathrm{Mm}^{3}$ LFG gas would be generated. After 2013, no more waste would be placed in the landfill.

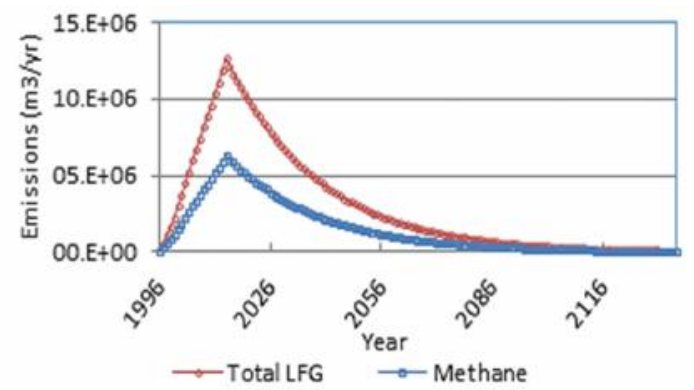

Figure 8: LFG generation from Deir El Balah landfill

For Al Fukhari landfill, Figure 9 shows the landfill gas production profile, which reached its maximum in 2041 where $8.4 \mathrm{Mm}^{3}$ methane would be produced and 16.9 $\mathrm{Mm}^{3}$ LFG gas would be generated. After 2040, no more waste would be placed in the landfill.

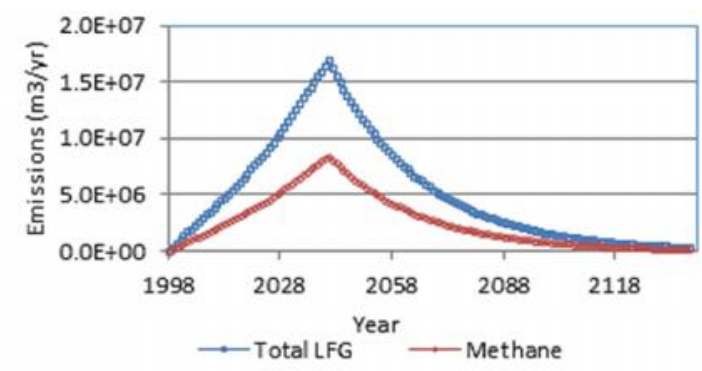

Figure 9: LFG generation from Al Fukhari landfill
The generated amount of landfill gas was used to estimate the power that could be generated from the landfill gas. A gas engine will be used to burn the landfill gas and estimate the power produced on site. A recovery rate of $50 \%$ of LFG and the efficiency of gas engine of $33 \%$ was assumed.

It can be seen at Figures 10, 11 and 12 that the profile of the graph for power generation annually is the same as the one for landfill gas production except that the power generation was computed as from 2013. The amount of power produced from total LFG in 2014 would be 84 $\mathrm{MWh}$ /day, $35 \mathrm{MWh} /$ day, 14MWh/day for Johr El Deek, Dier El Balah and Al Fukhari landfills, respectively.

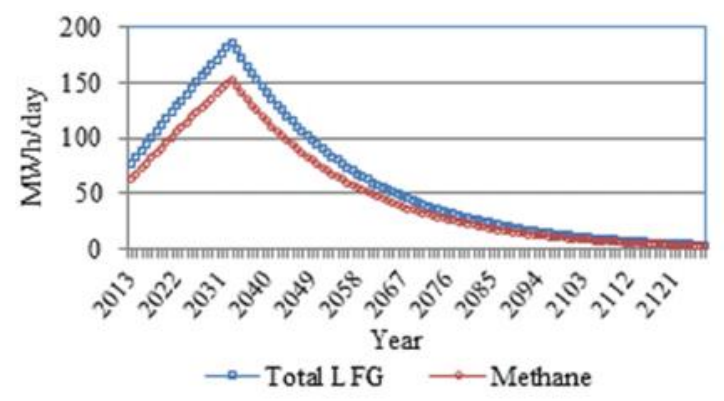

Figure 10: Average daily generated energy per year from Johr EI Deek landfill

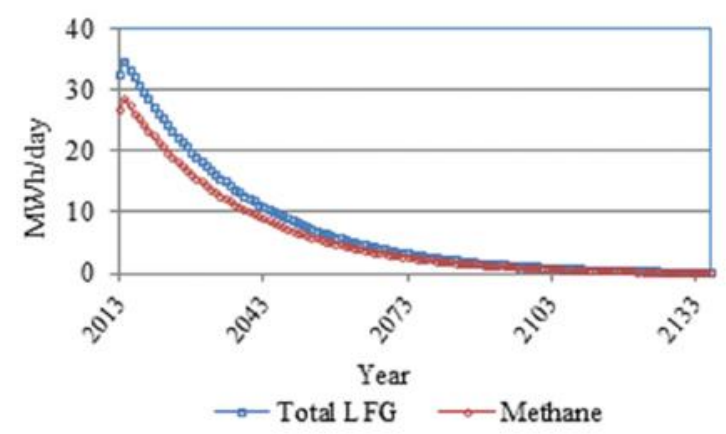

Figure 11: Average daily generated energy per year from Dier EI Balah landfill

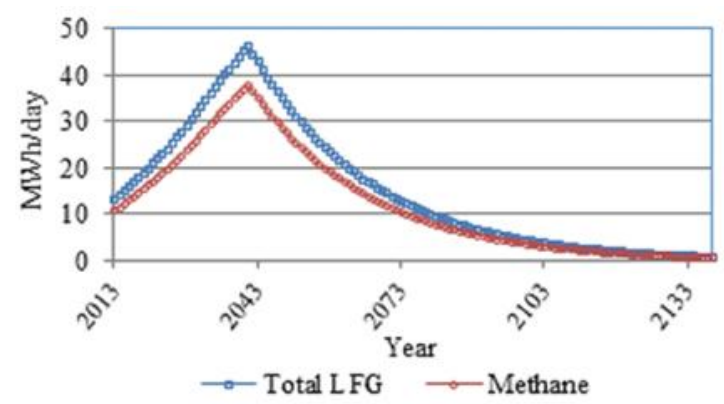

Figure 1: Average daily generated energy per year from Rafah landfill

As previously mentioned, landfill gas can be used in landfill gas-to-energy projects as fuel to power 
electricity-generating equipment. This landfill gas is collected by a system of well sand pipes installed throughout the landfill. The costs of a collection system depend on different site factors, such as landfill depth, number of wells required, etc.

Reciprocating internal combustion engines (IC engines) are the most widely used technology for generating electricity at landfills. More than two-thirds of the operational landfills where electricity is generated use this type of equipment. IC engines burn landfill gas in the presence of oxygen to run an engine. This engine is connected to a crank shaft that turns a generator and produces electricity. Table 6 shows U.S. EPA information about the performance and costs of three different commercially available gas-powered IC engines. These engines have a lifetime of 25-50 years when properly managed (Jaramillo et al., 2005).

\section{References}

[1] Naim A., (2014). Energy sector review in Gaza, Palestinian Energy and Natural Resources Authority Reports - PENRA Gaza, Palestine.

[2] PCBS Palestinian Central Bureau of Statistics, (2013). Population in the Palestinian territory. Ramallah, Palestine.

[3] Gisha, (2010). Electricity Shortage in Gaza: Who turned Out the Lights? Position Paper, GishaLegal Centre for Freedom of Movement.

[4] Energy Research Centre of the Netherlands (ECN), (2009). Bioenergy - a sustainable and reliable energy source.

[5] Seksan Udomsri, (2011). Combined Electricity Production and Thermally Driven Cooling from Municipal Solid Waste, Ph.D Thesis, Royal Institute of Technology, Stockholm, Sweden.

[6] El Baba, M. Y.; De Smedt, F., (2013). Solid Waste Management and Practices in Gaza Strip (Palestine).6th International Perspective on Water Resources \& Environment. Izmir, Turkey.
[7] Al Hmaidi, M., (2002). The development of a strategic waste management plan for Palestine, Review of the current situation: handling, transportation and disposal of waste, Negotiations Support Unit. Negotiations Affairs Department. Palestine.

[8] UNDP's Programme of Assistance to the Palestinian People (UNDP-PAPP). "Feasibility Study and Detailed Design for Solid Waste Management in the Gaza Strip", Final report, Version 3, 31 January 2012.

[9] Young, G. C., (2010). Municipal Solid Waste to Energy Conversion Processes: Economic, Technical and Renewable Comparisons, first ed., John Wiley, Hoboken, New Jersey.

[10] Enviros Consulting Limited, (2013). Incineration of Municipal Solid Waste, Department for Environment, Food and Rural Affairs - DEFRA.

[11] ATSDR, (2001). Landfill Gas Primer - An Overview for Environmental Health Professionals, Chapter 2: Landfill Gas Basics. Agency for Toxic Substances and Disease Registry (ATSDR).

[12] Muhaisen G., Mughari D. and Boraai D., (2012). Solid Waste Management For Gaza City: Composition Estimation Using (ASTM) Method And Prediction Using ANNs Technique. B.Sc. Thesis, Islamic University, Gaza, Palestine.

[13] Tchobanoglous G., Theisen H. and Vigil S., (1993). Integrated Solid Waste Management: Engineering principles and management issues, McGraw-Hill.

[14] Environmental Protection Agency (EPA), (2005). Landfill Gas Emissions Model (LandGEM) Version 3.02 User's Guide.

[15] Dinesh Surroop, Romeela Mohee, (2011). Power generation from landfill gas,2nd International Conference on Environmental Engineering and Applications (IPCBEE), Vol.17.

[16] http://www.wt-energy.com 